\title{
Co-treatment of a Carbon Deficient Domestic Wastewater with a Dairy Process Effluent for a Cost-effective Global Solution
}

\author{
Tamás Weinpel ${ }^{1 *}$, Vince Bakos¹, Andrea Jobbágy \\ 1 Department of Applied Biotechnology and Food Science, Faculty of Chemical Technology and Biotechnology, \\ Budapest University of Technology and Economics, H-1111 Budapest, Szt. Gellért tér 4., Hungary \\ * Corresponding author, e-mail: tweinpel@mail.bme.hu
}

Received: 15 July 2018, Accepted: 02 October 2018, Published online: 25 October 2018

\begin{abstract}
In order to avoid possible toxic and harmful effects on domestic wastewater treatment plants (WWTPs) as well as to meet influent criteria for the sewer network, industrial facilities are generally obliged to pre-treat their process effluents before discharging. Although industrial inflows may indeed cause operational nuisances (particularly in case of hidden shock-loads and toxic agents), possible effects are highly depending on the origin and quality of the effluent discharged. On the other hand, however, readily biodegradable carbon shortage of domestic wastewater has been commonly becoming the bottleneck of cost-effective biological nutrient ( $\mathrm{N}$ and $\mathrm{P}$ ) removal worldwide. The paper draws attention to the promising novel approach of combined wastewater treatment which may offer an optimal solution by shifting the inlet C:N ratio into a favorable range for efficient denitrification and biological excess P-removal. At the start of the study the temporarily decreased treatment efficiency of the domestic WWTP investigated had been basically attributed to the dairy wastewater discharged from an ice cream factory of the catchment area. However, both on-site profile measurements and mathematical simulations suggested that instead of a direct harming effect, aeration was insufficient, and dissolved oxygen concentration had to be increased in the aerobic reactors for efficient nitrification, especially in winter season. The studies also confirmed that with adequate aeration, efficiency of denitrification would have considerably decreased without using the dairy effluent as complementary carbon source or expensive external C-source would have been required. However, in order to save unnecessary aeration costs, overdosing of dairy effluent has to be carefully avoided.
\end{abstract}

\section{Keywords}

activated sludge, combined domestic and dairy wastewater treatment, mathematical simulation, nutrient removal

\section{Introduction}

In accordance with the worldwide expanding tendency to decrease amount of pollutants discharged from industrial facilities, strict requirements have been worked out also in this respect. Since poor performance of the receiving domestic wastewater treatment plant is generally attributed to the industrial part of the influent, debates may end up with treating the two kinds of wastewater separately. However, this may not be the appropriate solution, especially when the domestic influent with high $\mathrm{N}$ - and $\mathrm{P}$-content is in shortage of C-source and may require external carbon dosing in order to reach proper nutrient removal efficiency. While external carbon dosing is getting more and more common supported by high level research $[1,2]$, co-treatment of domestic wastewater with marginal or poor C-availability with carbon-rich and nutrient deficient wastewater of the food industry has got less attention, but may mutually be advantageous and cost-effective in certain cases. In previous studies, acetate was reported as the most suitable $\mathrm{C}$-source for denitrification [3]. However, in many cases, the problem of high costs of commercial organic compounds (as acetate) can be the bottleneck of full-scale application.

In Hungary, mainly due to the long retention time in the sewer systems, shortage of C-source is frequently experienced coupled with high influent ammonia concentration $[4,5]$, and this fact causes problems in meeting N-removal requirements. Furthermore, onsite sludge digestion, moreover, co-fermentation of different wastes, as environment-friendly way of disposal with enhancement of methane production may lead to large additional N-loads without covering the increased C-source demand of denitrification [6]. According to Fux et al. [7] 
$15-20 \%$ of total influent N-load may derive from sludge processing overflows. This value may even considerably increase through co-digestion.

On the other hand, it has been experienced that dairy wastewater is a biologically degradable, non-toxic substrate. These food industrial effluents could be good alternative $\mathrm{C}$-sources, as a result of their high $\mathrm{C}$ to $\mathrm{N}$ ratios and high content of readily biodegradable fraction [8-10], in accordance with the fact that the potential of $\mathrm{C}$-source for denitrification depends on its biodegradability or on the amount of readily biodegradable COD fraction [11]. Applicability of a large number of different external C-sources has already been investigated in numerous studies $[1,2]$. It has also been highlighted that better understanding of biodegradation pathways, advanced model identification as well as extended COD fractionation by introducing additional model variables may also be needed for providing accurate mathematical models (e.g. expanded ASM2d, [12]).

In an aerobic activated sludge system the $\mathrm{BOD}_{5}: \mathrm{N}: \mathrm{P}$ ratio is recommended to be 100:5:1 [13] in order to avoid nutrient deficiency, however, depending on the quality of the $\mathrm{C}$-source it may vary remarkably $[14,15]$. Wastewater of milk products and ice cream production plants can usually be characterized by lower $\mathrm{N}$ - and P-content: $\mathrm{BOD}_{5}: \mathrm{N}: \mathrm{P}$ ratio may remain at 100:1.6:1.6 [16] or be even lower 100:0.1:0.5 [17]. Therefore, it could be assumed that process effluent coming with high rbCOD (readily biodegradable Chemical Oxygen Demand) content from an ice cream factory may remarkably improve denitrification efficiency and could be successfully treated together with the domestic influent. Previous studies focused on denitrification potential of dairy wastewater have got to different recommendations for the appropriate influent $\mathrm{COD} / \mathrm{NO}_{3}-\mathrm{N}$ ratios from 4.6 [18] up to 10 [11]. This is very important showing that dairy wastewater quality may also differ from site to site and its readily biodegradable
COD content has to be carefully investigated for finding appropriate local solutions. Whereas separate treatment could require dosing external $\mathrm{C}$-source into the domestic plant and supplementary $\mathrm{N}$ - and P-sources to the industrial pre-treatment plant raising significant additional operational costs on both sides.

The purpose of the research has been to find the causes of the temporarily decreased treatment efficiency of the Hungarian domestic WWTP investigated, receiving process effluent from an ice cream factory, and to explore possible solutions for improvement. Effects of bioreactor arrangement and operation were investigated in cases when the dairy wastewater was introduced into the domestic treatment plant after or without pre-treatment. The appropriate conditions for efficient co-treatment have been carefully investigated for finding costeffective local solution which does not require expensive external C-source at the domestic WWTP, neither costly pre-treatment and nutrient source dosing to the ice cream factory effluent.

\section{Materials and methods}

\subsection{Description of the bioreactor arrangement and operation of the domestic WWTP}

The WWTP investigated received on average 2,000$2,200 \mathrm{~m}^{3} / \mathrm{d}$ influent with approximately $200 \mathrm{~m}^{3} / \mathrm{d}$ industrial part coming from the production of ice cream, especially in summer season. The modified UCT (University of Cape Town) activated sludge system applied is shown in Fig. 1. The activated sludge unit had staged anaerobic and anoxic selectors followed by an aerated step for nitrification. The wastewater treatment line was operated with a $960 \mathrm{~m}^{3} / \mathrm{d}$ rate of sludge recirculation from the secondary clarifier to the $3^{\text {rd }}$ anaerobic basin with a nitrate recirculation $\left(9,360 \mathrm{~m}^{3} / \mathrm{d}\right)$ directed from the $3^{\text {rd }}$ aerobic basin to the first anoxic reactor, and an anoxic recirculation $\left(960 \mathrm{~m}^{3} / \mathrm{d}\right)$ from the $3^{\text {rd }}$ non-aerated reactor into the $1^{\text {st }}$ one.

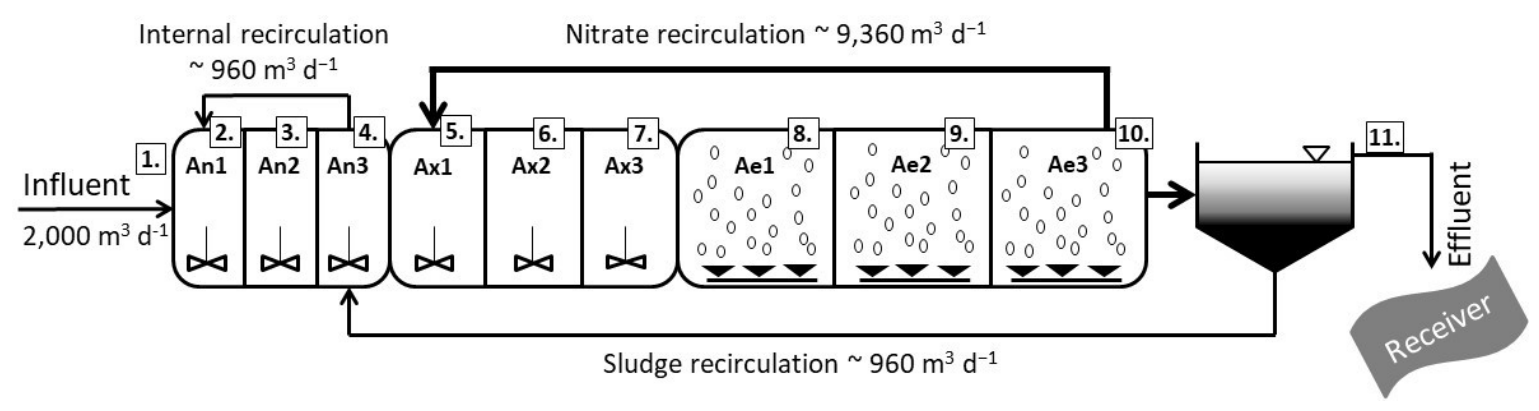

Fig. 1 Technological layout of the domestic activated sludge treatment plant with the sampling points indicated by numbers (Reactor volumes: An: $3 \times 85 \mathrm{~m}^{3}$, Ax: $3 \times 143 \mathrm{~m}^{3}$, Ae: $3 \times 555 \mathrm{~m}^{3}$ ). 
The effluent limit values for the WWTP were $125 \mathrm{mg} \mathrm{COD} / \mathrm{L}, 25 \mathrm{mg} \mathrm{BOD}_{5} / \mathrm{L}, 10 \mathrm{mg} \mathrm{NH}_{4}-\mathrm{N} / \mathrm{L}$, $30 \mathrm{mg}$ TN/L, $5 \mathrm{mg} \mathrm{TP} / \mathrm{L}$ and $35 \mathrm{mg}$ TSS/L. It is important to emphasize, however, that according to the Hungarian regulations a certain "environmental load" fee has to be paid on the basis of the amount of pollutants discharged into the receiving body even if the concentrations meet the criteria. This is a pressure on operators for providing as low as reasonably possible and affordable effluent concentration levels in the treated wastewater.

\subsection{Preliminary data analysis}

Research activities were started with detailed analysis of the influent and effluent data available for 4 years in order to investigate the performance as well as to create appropriate input parameter values for the mathematical simulation. The first aim was to find out the reason of temporarily decreased nitrification rates, causing increased effluent ammonia concentrations. The main possible reasons were assumed to be the followings: (1) increased influent COD load attributable mainly to the process effluent from the ice cream factory, being harmful or causing significantly decreased sludge age and/or decreased dissolved oxygen (DO) level, (2) insufficient oxygen supply in the aerobic bioreactors, (3) inappropriate bioreactor arrangements, (4) unfavorable temperature.

\subsection{On-site pollutant concentration profile measurements}

Additional data were acquired by on-site measurements tracking the treatment process through determination of the concentration profiles of different pollutants. Samples were taken from the domestic plant during 3 sampling campaigns at the sampling points shown in Fig. 1. Temperature, $\mathrm{pH}$ and DO levels as well as concentrations of dissolved COD, $\mathrm{NH}_{4}-\mathrm{N}, \mathrm{NO}_{3}-\mathrm{N}, \mathrm{NO}_{2}-\mathrm{N}, \mathrm{TN}$ (Total Nitrogen) and $\mathrm{PO}_{4}-\mathrm{P}$ were measured. MLSS (Mixed Liquor Suspended Solids) concentration and settling characteristics of activated sludge were also determined. For raw inlet and pre-clarified wastewater total $\mathrm{COD}, \mathrm{BOD}_{5}$ (5-day Biochemical Oxygen Demand) and TSS (Total Suspended Solids) concentrations were also determined.

\subsection{Mathematical simulation studies}

Mathematical simulation studies aimed to reveal the causes of the decreased nitrification efficiency as well as finding solutions for the efficient co-treatment of the carbon deficient domestic wastewater and the dairy process effluent. Simulation studies were carried out with the use of BIOWIN ${ }^{\odot}$ software (by applying mathematical model ASM2d) [19] applying different bioreactor arrangements and biomass concentrations at different temperatures. Data of on-site concentration profile measurements were used for appropriate model fitting.

\section{Results and discussion}

\subsection{Evaluation of the preliminary data}

Operation conditions of the activated sludge treatment plant are illustrated in Fig. 2 and 3, showing highly fluctuating influent $\mathrm{COD}, \mathrm{BOD}_{5}$ and $\mathrm{NH}_{4}-\mathrm{N}$ concentrations in the ranges of 200-1,400 $\mathrm{mg} \mathrm{COD} / \mathrm{L}, 190-1,100 \mathrm{mg} \mathrm{BOD} / \mathrm{L}$ and $35-90 \mathrm{mg} \mathrm{NH}_{4}-\mathrm{N} / \mathrm{L}$, respectively. Although it had been basically meant to be the co-treatment of the dairy wastewater, the high peaks can partly be attributed to uneven operation of the sludge processing resulting in high $\mathrm{N}$ - and P-contents.

Data depicted in Fig. 2 show, however, that increased effluent ammonia concentrations may sometimes be related to high influent COD loads (marked as II. and III. periods). On the contrary, some other periods (e.g. I. period) confirm that the reason of insufficient nitrification cannot be the high influent organics. Comparing the influent COD level of the WWTP to the effluent COD concentrations of the ice cream factory could not unambiguously prove that dairy wastewater was responsible for the high influent COD peaks of the domestic WWTP.

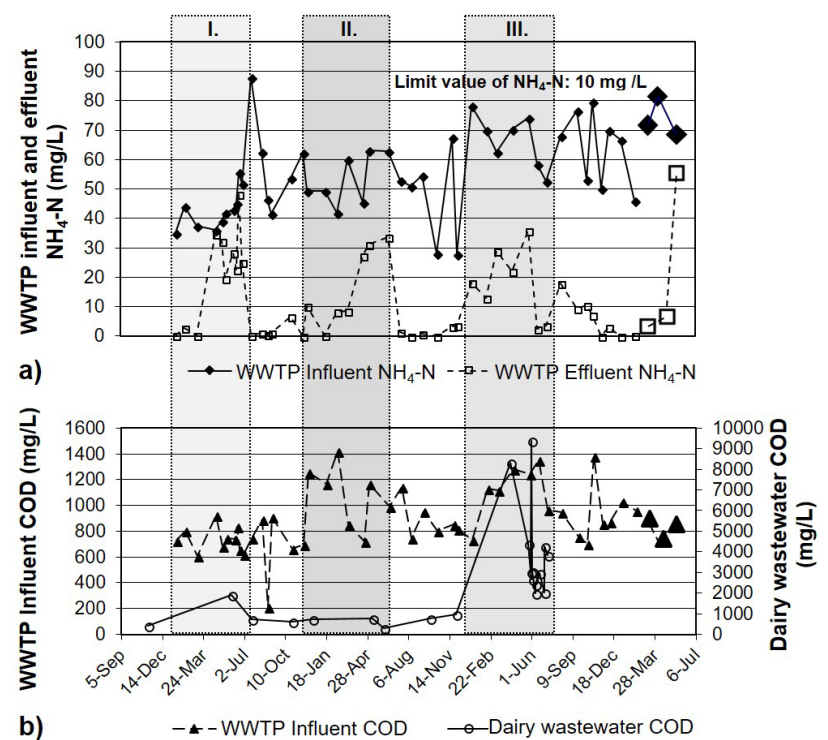

Fig 2 (a) United influent and effluent $\mathrm{NH}_{4}-\mathrm{N}$ concentrations, and

(b) united influent total COD concentrations of the WWTP and total COD concentration values of the dairy wastewater (last three data indicated with large dots were detected during the profile measurements). 


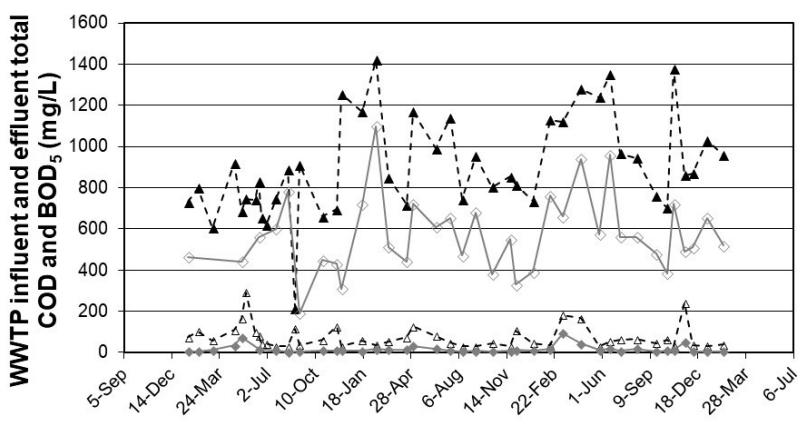

a) $-\triangle$ Influent COD $\rightarrow$ Influent BOD5 $-\rightarrow$ - Effluent COD $\rightarrow$ - Effluent BOD5

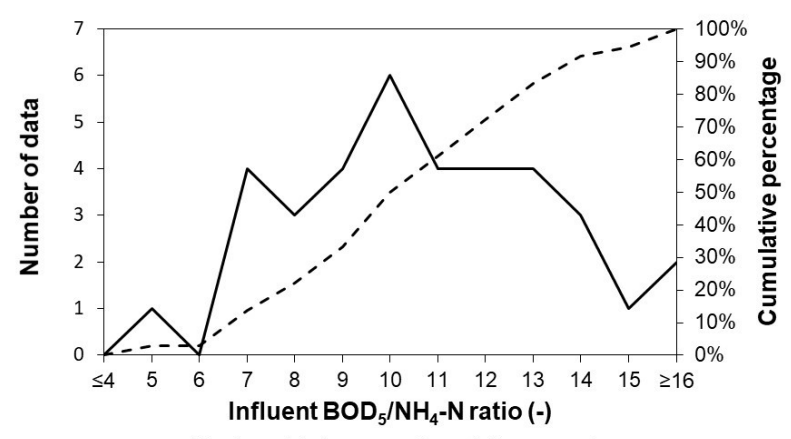

b)

- Number of data - - Cumulative percentage

Fig. 3 (a) Influent and effluent total $\mathrm{COD}$ and $\mathrm{BOD}_{5}$ concentrations, and (b) statistical evaluation of influent $\mathrm{BOD}_{5} / \mathrm{NH}_{4}-\mathrm{N}$ ratios (total number of data: 36 ).

Therefore, based on the evaluated four-year operational data, the temporarily decreased nitrification efficiency could not be brought in direct connection with the co-treated dairy process effluent.

As it can be observed in Fig. 3 (a), tendencies and ratios of $\mathrm{COD}$ and $\mathrm{BOD}_{5}$ concentration data show, that major amount of the influent $\mathrm{C}$-source may be readily biodegradable (average $\mathrm{BOD}_{5} / \mathrm{COD}$ ratio is 0.61 ), being favorable for efficient denitrification. Major amount of this C-source can be attributed to the process effluent of the ice cream factory (see Fig. 2 (b)). Fig. 3 (b) presents the results of the statistical evaluation of the influent $\mathrm{BOD}_{5} / \mathrm{NH}_{4}-\mathrm{N}$ ratios for the four-year period investigated. Since most of the values exceeded 6 considered to refer to "good" carbon availability [20], data evaluation confirmed that good denitrification capacity can be mainly attributed to the dairy influent.

\subsection{Results of the on-site concentration profile measurements}

On-site measurements were carried out for tracking the treatment process. Samples were taken and measurements were carried out on March $26^{\text {th }}\left(1^{\text {st }}\right.$ Profile, at $\left.12.5^{\circ} \mathrm{C}\right)$, on March $31^{\text {st }}\left(2^{\text {nd }}\right.$ Profile, at $13.2{ }^{\circ} \mathrm{C}$ ), and on May $11^{\text {th }}$ $\left(3^{\text {rd }}\right.$ Profile, at $18.2^{\circ} \mathrm{C}$ ) at the 11 sampling points indicated by numbers in Fig. 1. Profile measurements suggested that aeration was insufficient in the aerobic reactors, with dissolved oxygen concentrations being generally $<0.5 \mathrm{mg} / \mathrm{L}$ (see Fig. 4 (a)). Since $\mathrm{K}_{\mathrm{SO} 2}$ value for nitrifiers is known to be significantly higher $(0.75 \mathrm{mg} \mathrm{DO} / \mathrm{L},[20])$ than those of heterotrophic bacteria, the measured DO level could be assumed as a limiting factor of efficient nitrification. On the other hand, in the non-aerated reactors, considered previously as anaerobic or anoxic basins, undesirably high dissolved oxygen concentrations were detected $(>0.5 \mathrm{mg} / \mathrm{L})$ that could have hindered denitrification as well as P-release both metabolically and kinetically [21] in the non-aerated bioreactors. This kind of oxygen penetration has been efficiently avoided by seal-covering the reactor surface at North-Budapest WWTP in Hungary [22, 23].

Despite the low temperature, relatively high influent ammonia concentrations (75-88 $\mathrm{mg} \mathrm{NH}_{4}-\mathrm{N} / \mathrm{L}$ ) and low DO levels, during the first and second profile measurements effluent $\mathrm{NH}_{4}-\mathrm{N}$ concentrations were far below the $10 \mathrm{mg} \mathrm{NH}$-N/L limit value (see Fig. 4 (b)). Moreover, the measured effluent $\mathrm{NO}_{3}-\mathrm{N}$ concentrations proved to be on the edge of detectability, referring to possibly simultaneous nitrification and denitrification in the bioreactors. However, during the third profile measurement, at very similar influent ammonia $\left(68 \mathrm{mg} \mathrm{NH}_{4}-\mathrm{N} / \mathrm{L}\right)$ and $\mathrm{PO}_{4}$-P (5.9 mg P/L) concentrations both biological $\mathrm{N}$ - and P-removal were found to be insufficient and even effluent COD concentrations exceeded the limit criteria (see Fig. 4 (b)-(d)). Decreased treatment efficiency may well be attributed to a high dairy process effluent load at the insufficient aeration. Since nitrification proved to be hindered despite the relatively high temperature, nitrate could not be used as electron acceptor. Dissolved COD must have been basically removed by intentional and unintentional aeration. It is interesting to observe that a pronounced P-release was detected in the basins serving originally for nitrate removal. However, the amount of $\mathrm{PO}_{4}$-P taken up in the $1^{\text {st }}$ aerated basin was released again in the $2^{\text {nd }}$ and $3^{\text {rd }}$ ones. This time MLSS concentration was found to be significantly lower $(5.7 \mathrm{~g} / \mathrm{L})$ compared to those of the first and second sampling days (ca. $8 \mathrm{~g} / \mathrm{L}$ ). This may refer to a shorter sludge age, however, oxygen deficiency partly caused by high influent COD load can be assumed to be the main reason of the poor performance.

\subsection{Results of mathematical simulation studies}

In order to widely investigate the impact of possible influencing factors on the treatment efficiency, mathematical 

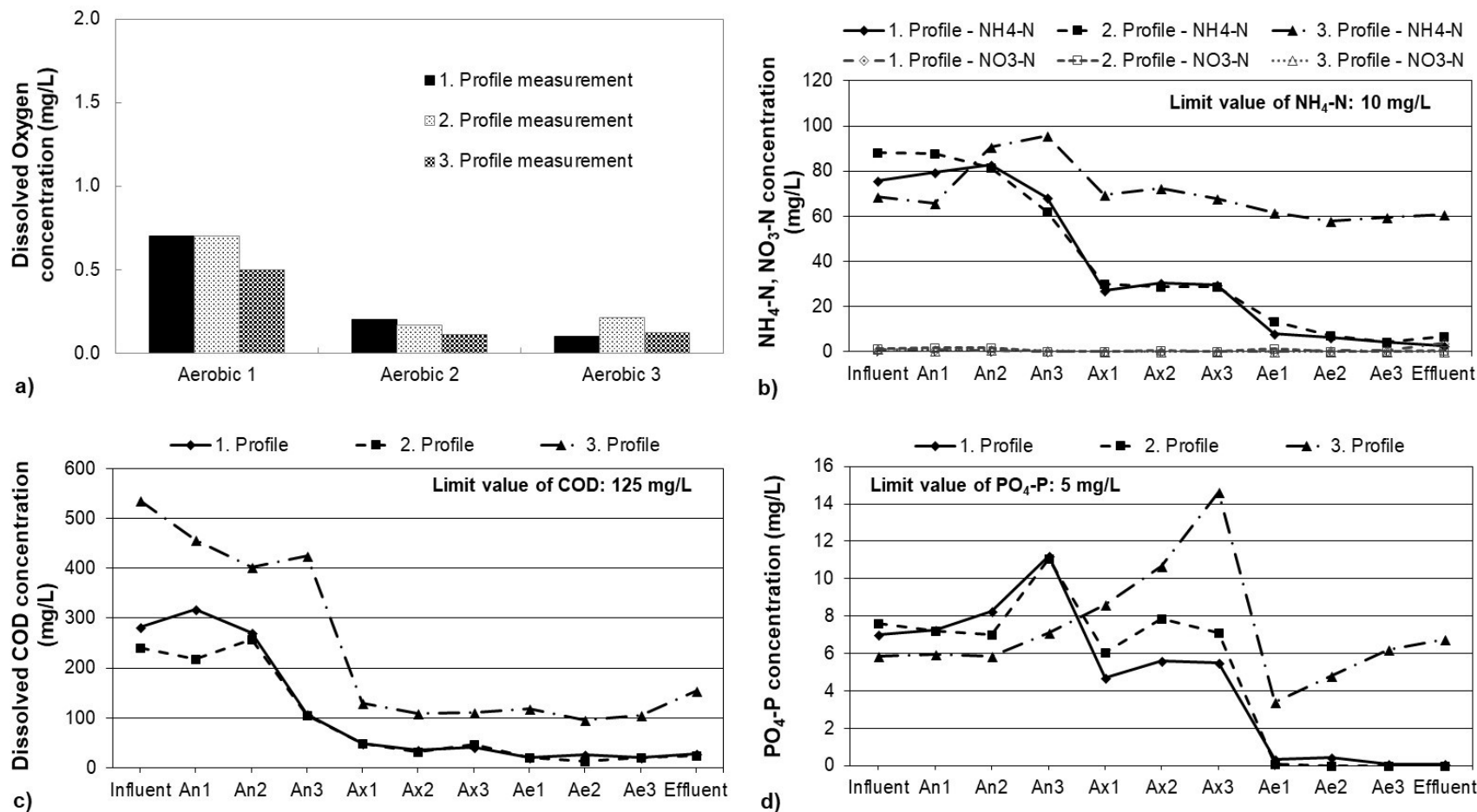

Fig. 4 Measured (a) dissolved oxygen concentrations in the aerated reactors, (b) $\mathrm{NH}_{4}-\mathrm{N}_{\text {and }} \mathrm{NO}_{3}-\mathrm{N}$ concentrations, (c) dissolved COD and (d) $\mathrm{PO}$ - $\mathrm{P}$ concentrations at the time of the three profile measurements.

Table 1 Applied parameter settings for mathematical simulation studies.

\begin{tabular}{|c|c|c|c|c|c|}
\hline $\begin{array}{l}\text { MLSS concentration } \\
(\mathrm{g} / \mathrm{L})\end{array}$ & $\begin{array}{c}\text { Wastewater } \\
\text { temperature }\left({ }^{\circ} \mathrm{C}\right)\end{array}$ & $\begin{array}{l}\text { Influent Flow Rate } \\
\qquad\left(\mathrm{m}^{3} / \mathrm{d}\right)\end{array}$ & $\begin{array}{l}\text { Influent total COD } \\
\qquad(\mathrm{mg} / \mathrm{L})\end{array}$ & Arrangements & $\begin{array}{l}\text { DO of aerated reactors applied } \\
\text { for calculations }(\mathrm{mg} / \mathrm{L})\end{array}$ \\
\hline \multirow{5}{*}{8 and 5} & \multirow{5}{*}{12 and 22} & \multirow{5}{*}{2,500} & 483: low ${ }^{1}$ & Current & 0.5 \\
\hline & & & 660: low $^{2}$ & Current + DO up & 2.0 \\
\hline & & & 783: moderate ${ }^{3}$ & BioP & 2.0 \\
\hline & & & 900: average $^{4}$ & Pre-DN & 2.0 \\
\hline & & & 1,200: high $^{5}$ & Pre- and post-DN & 2.0 \\
\hline
\end{tabular}

${ }^{1,2,3}$ Influent COD concentrations may occur in the absence of $200 \mathrm{~m}^{3} / \mathrm{d}$ dairy wastewater $\left(\mathrm{COD}: 5,200 \mathrm{mg} / \mathrm{L}^{1}, 3,000 \mathrm{mg} / \mathrm{L}^{2}, 1,500 \mathrm{mg} / \mathrm{L}^{3}\right.$ )

${ }^{4}$ Average influent COD concentrations based on full-scale data measured previously

${ }^{5}$ Maximum value for influent COD concentrations based on full-scale data measured previously

simulations were carried out using BIOWIN $^{\circ} 3.1$ software (with ASM2d).

Model calibration was done by applying detailed data of on-site profile measurements and background operational data of the sampling days. Validation was carried out with the use of historical data supplied by the operator of the previous years with the selection of different operational periods, calculating with the Current system configuration (see Fig. 1). As it is illustrated in Table 1 and Fig. 5 further calculations were made using different parameter settings (i.e. at 2,500 $\mathrm{m}^{3} / \mathrm{d}$ influent flow rate, at biomass concentrations of 5 and $8 \mathrm{~g} / \mathrm{L}$ and applying different bioreactor arrangements: Current, Current $+D O$ up (see Fig. 1), Pre-DN, Pre- and post-DN, as well as BioP(see Fig. 5).
The basic concept was to investigate the activated sludge treatment efficiency at different influent COD concentrations considering the presence at different rates or absence (i.e. pre-treatment before discharging into the sewer) of dairy wastewater in the influent. In case of applying pre-treated dairy wastewater, the influent COD concentration was considered to be obviously lower. The influent COD concentrations were calculated on the basis of previous years' data of the discharged dairy wastewater and influent domestic wastewater, respectively.

Results of the mathematical simulation studies have been presented in Figs. 6-9, and show that in order to maintain good and stable nitrification efficiency, dissolved oxygen concentration had to be increased from 0.5 to approximately $2 \mathrm{mg} / \mathrm{L}$ in case of keeping the 


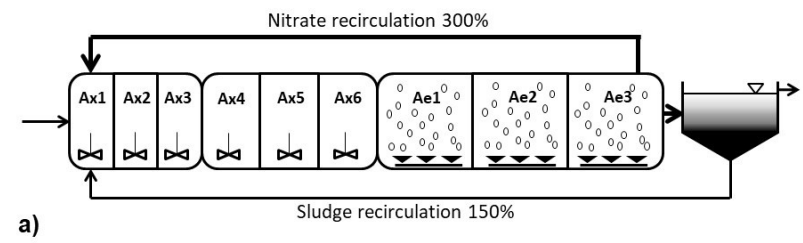

a)
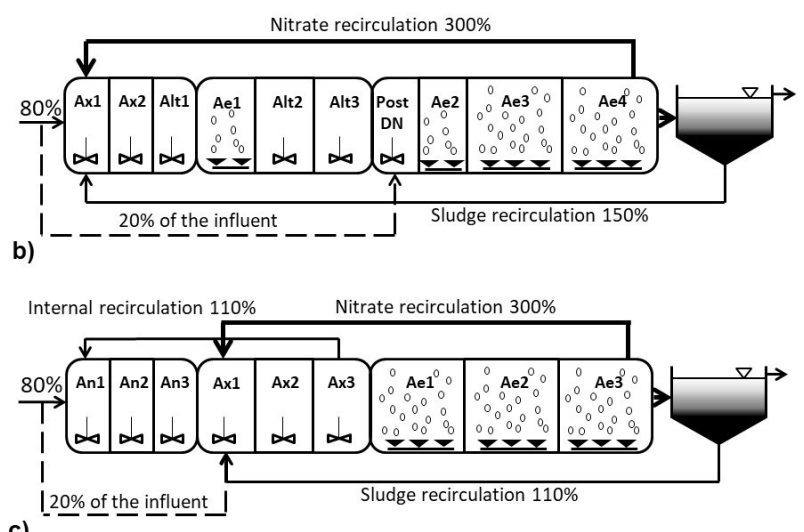

c)

Fig. 5 Bioreactor arrangements investigated by the mathematical simulations: (a) Pre-DN, (b) Pre- and post-DN and (c) BioP system.

$Q=2,500 \mathrm{~m}^{3} / \mathrm{d} ; \mathrm{T}=12^{\circ} \mathrm{C}, \mathrm{MLSS}=8 \mathrm{~g} / \mathrm{L}$

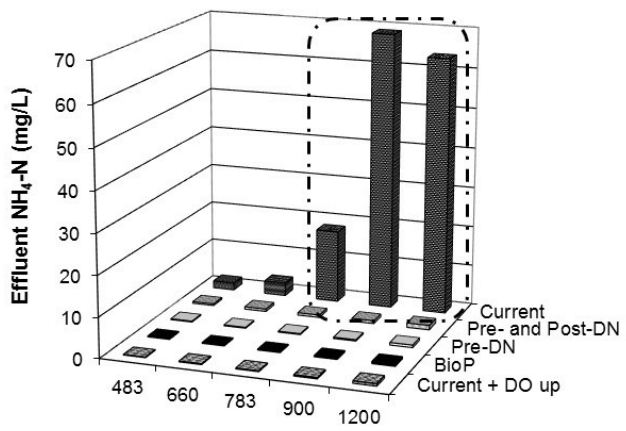

a)

Influent total $\operatorname{COD}(\mathrm{mg} / \mathrm{L})$ current bioreactor arrangement, especially in winter season (see Fig. 6 (a) and 7 (a)). In winter season effluent ammonia criteria could be achieved at MLSS concentration of both 5 and $8 \mathrm{~g} / \mathrm{L}$. However, effluent ammonia concentration could barely achieve the requirement of $10 \mathrm{mg} \mathrm{NH}_{4}-\mathrm{N} / \mathrm{L}$ at the highest influent COD load even in case of sufficient aeration at biomass concentration of $5 \mathrm{~g} / \mathrm{L}$ (see Fig. 7 (a)). Influent total COD concentration of $1,200 \mathrm{mg} / \mathrm{l}$ (with a dissolved COD fraction of ca. $600 \mathrm{mg} / \mathrm{l}$ ) shown in Figs. 6-9 is considered to basically represent the same inlet wastewater quality as found during the $3^{\text {rd }}$ on-site profile measurement.

Results showed that biomass concentration could be decreased from 8 to $5 \mathrm{~g} / \mathrm{L}$, in case of sufficient aeration and only the highest organic load would need higher MLSS concentration in order to stay safely under the effluent $\mathrm{NH}_{4}-\mathrm{N}$ criteria. Investigations on denitrification efficiency proved that in case of low inlet dissolved COD concentrations (i.e. influent total COD of 483 and

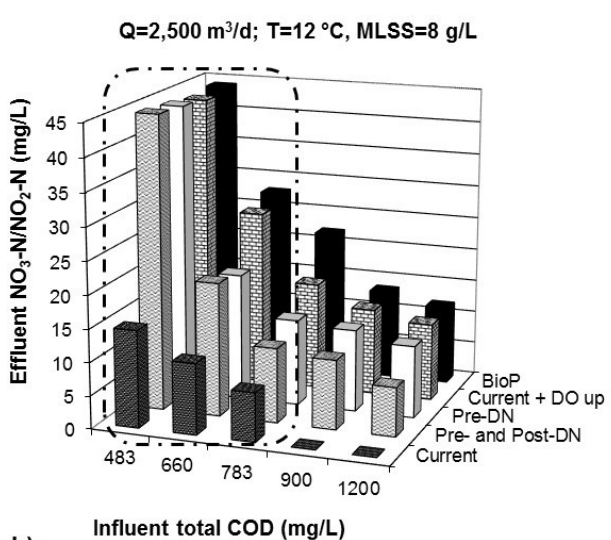

b)

Fig. 6 (a) Insufficient nitrification due to currently low oxygen supply; and (b) efficient nitrogen removal with dairy wastewater in winter season $\left(\mathrm{Q}=2,500 \mathrm{~m}^{3} / \mathrm{d}, \mathrm{MLSS}=8 \mathrm{~g} / \mathrm{L}\right)$.
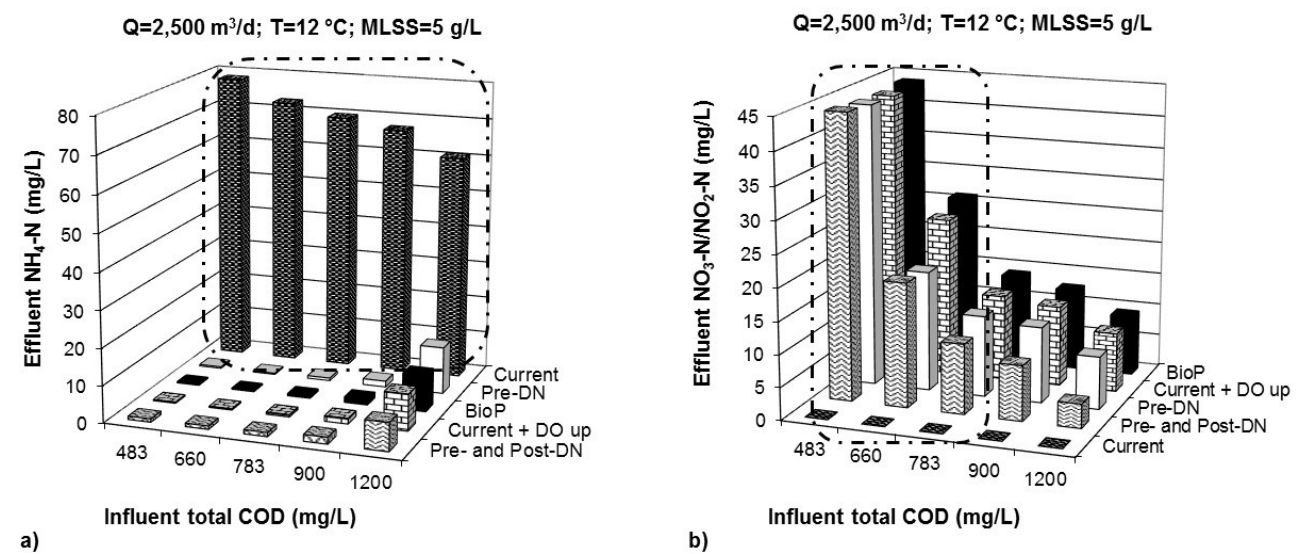

Fig. 7 (a) Insufficient nitrification due to currently low oxygen supply; and (b) efficient nitrogen removal also in winter season with dairy wastewater $\left(\mathrm{Q}=2,500 \mathrm{~m}^{3} / \mathrm{d}, \mathrm{MLSS}=5 \mathrm{~g} / \mathrm{L}\right)$. 
$Q=2,500 \mathrm{~m}^{3} / \mathrm{d} ; \mathrm{T}=22^{\circ} \mathrm{C}, \mathrm{MLSS}=8 \mathrm{~g} / \mathrm{L}$

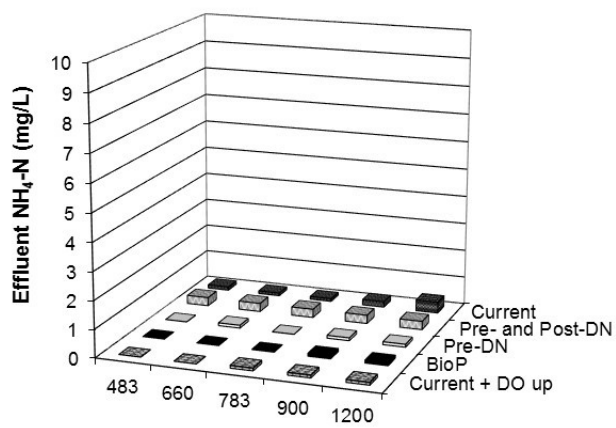

Influent total COD $(\mathrm{mg} / \mathrm{L})$

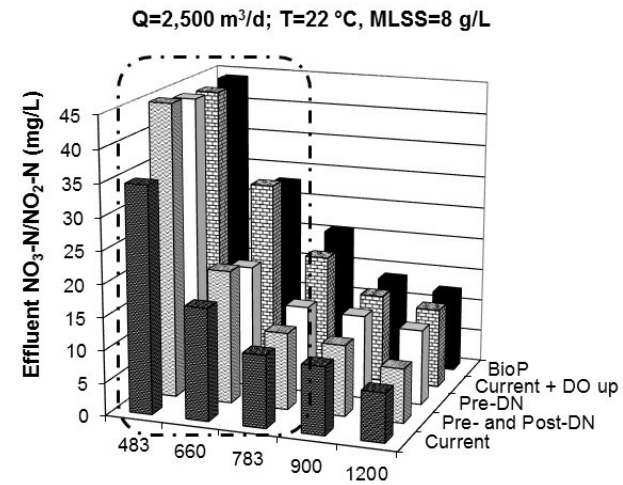

b)

Influent total COD (mg/L)

Fig. 8 (a) Stable nitrification, but (b) inefficient denitrification without dairy wastewater (at inlet COD concentrations under 600-700 mg/l) in summer season $\left(\mathrm{Q}=2,500 \mathrm{~m}^{3} / \mathrm{d}, \mathrm{MLSS}=8 \mathrm{~g} / \mathrm{L}\right)$.
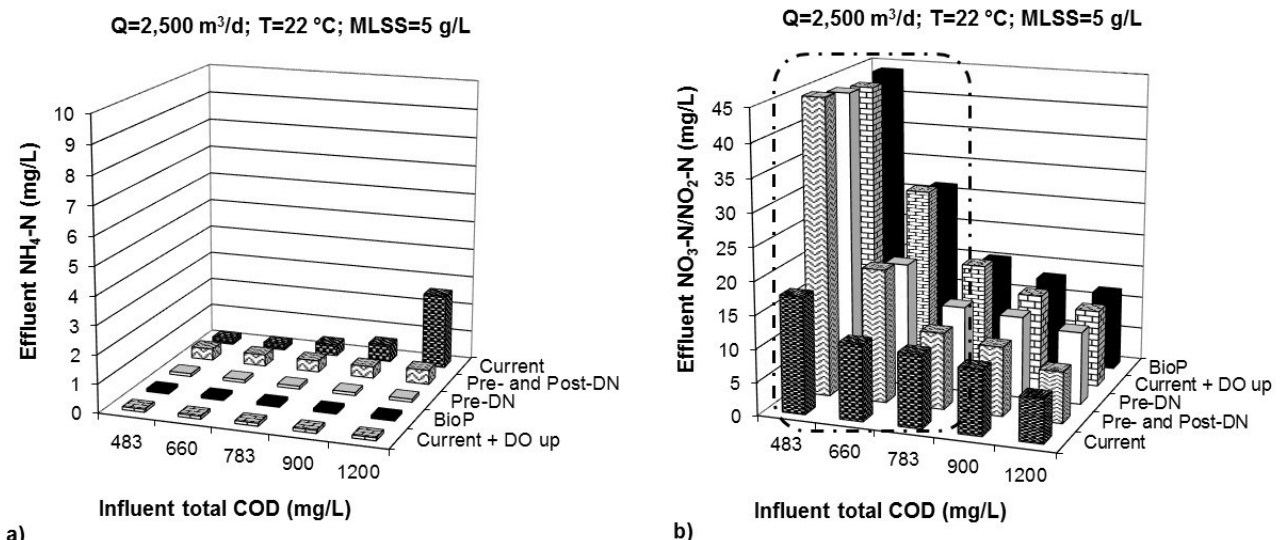

Fig. 9 (a) Stable nitrification, but (b) inefficient denitrification without dairy wastewater (at inlet COD concentrations under 600-700 mg/l) in summer season $\left(\mathrm{Q}=2,500 \mathrm{~m}^{3} / \mathrm{d}, \mathrm{MLSS}=5 \mathrm{~g} / \mathrm{L}\right)$.

$660 \mathrm{mg} / \mathrm{L}$, representing the influent total COD concentration range detected during the $1^{\text {st }}$ and $2^{\text {nd }}$ on-site profile measurements and referring to $\mathrm{BOD}_{5} / \mathrm{NH}_{4}-\mathrm{N}$ ratios of 3.18 and 5.46, respectively) the effluent TN requirement could not be achieved without dosing external $\mathrm{C}$-source both in winter and summer seasons. The largest amount of external C-source would be needed in case of Current + DO up and BioP configurations (see Fig. 6 (b), 7 (b), 8 (b) and 9 (b)). Dosing external C-source can be avoided for none of the configurations investigated at influent COD concentrations lower than 650-700 mg/L (i.e. at a $\mathrm{BOD}_{5} / \mathrm{NH}_{4}-\mathrm{N}$ ratio below 6 ). These findings are in good accordance with the influent $\mathrm{C}: \mathrm{N}$ ratios described by Grady et al. [20], namely, a $\mathrm{BOD}_{5} / \mathrm{NH}_{4}-\mathrm{N}$ ratio lower than 4 belongs to severe carbon deficiency, and the range between 4 and 6 represents marginal carbon availability, because it does not meet the safe criteria of efficient denitrification.

\section{Conclusions}

Careful evaluation of previous data, on-site measurements and mathematical simulations verified that the temporarily decreased N-removal efficiency of a domestic WWTP receiving industrial discharge of an ice cream factory could not be directly attributed to a possibly toxic effect of dairy wastewater inflow. Moreover, the dairy wastewater proved to serve as readily biodegradable C-source having thereby a favorable impact on denitrification efficiency. Profile measurements showed that dissolved oxygen concentration had to be increased in the aerobic reactors in order to achieve stable nitrification, also during winter season. However, unnecessarily increased influent load of dairy process effluent, exceeding the C-source requirement for nutrient removal, could lead to wasting energy by increased aeration efficiency for COD removal. Mathematical simulation studies confirmed that aeration was insufficient in winter season and suggested that with 
adequate aeration for nitrification effluent nitrate concentration could increase remarkably in case of the absence of dairy wastewater inflow. Thus, appropriate quantity of industrial wastewater is a key requirement for stable and cost-effective biological N-removal, otherwise dosing expensive external $\mathrm{C}$-source would be required. Both measured data and simulation results (gained by a validated model based on full-scale data) showed that dosing external C-source at this investigated WWTP could not be avoided at influent total COD concentrations lower than $650-700 \mathrm{mg} / \mathrm{L}$ (i.e. below an influent $\mathrm{BOD}_{5} / \mathrm{NH}_{4}-\mathrm{N}$ ratio of ca. 6). In our case study for achieving safe and efficient denitrification, a moderate dairy wastewater inlet load proved to be necessary resulting in an influent total COD concentration of $783 \mathrm{mg} / \mathrm{L}$ (referring to a $\mathrm{BOD}_{5} / \mathrm{NH}_{4}-\mathrm{N}$ ratio of 6.47 and a COD/TKN ratio of 8.96). Although

\section{References}

[1] Swinarski, M., Makinia, J., Czerwionka, K., Chrzanowska, M., Drewnowski, J. "Comparison of the Effects of Conventional and Alternative External Carbon Sources on Enhancing the Denitrification Process", Water Environment Research, 81(9), pp. 896-906, 2009.

https://doi.org/10.2175/106143009X407438

[2] Czerwionka, K., Makinia, J., Kaszubowska, M., Majtacz, J., Angowski, M. "Distillery wastes as external carbon sources for denitrification in municipal wastewater treatment plants", Water Science and Technology, 65(9), pp. 1583-1590, 2012.

https://doi.org/10.2166/wst.2012.050

[3] Gerber, A., Mostert, E. S., Winter, C. T., de Villiers, R. H. "The effect of acetate and other short-chain carbon compounds on the kinetics of biological nutrient removal", Water SA, 12(1), pp. 7-12, 1986.

[4] Tardy, G. M., Bakos, V., Jobbágy, A. "Conditions and technologies of biological wastewater treatment in Hungary", Water Science and Technology, 65(9), pp. 1676-1683, 2012.

https://doi.org/10.2166/wst.2012.062

[5] Jobbágy, A., Palkó, Gy., Weinpel, T., Makó, M. "Comparative studies on the differently operated trains of the North-Budapest Wastewater Treatment Plant", Water Science and Technology, 65(10), pp. 1801-1808, 2012.

https://doi.org/10.2166/wst.2012.079

[6] Weinpel, T., Bakos, V., Jobbágy, A. "Effects of increased influent nitrogen load on a part-time aerated activated sludge system", Water Practice and Technology, 8(1), pp. 18-26, 2013. https://doi.org/10.2166/wpt.2013.003

[7] Fux, C., Boehler, M., Huber, P., Brunner, I., Siegrist, H. "Biological treatment of ammonium-rich wastewater by partial nitritation and subsequent anaerobic ammonium oxidation (anammox) in pilot plant", Journal of Biotechnology, 99(3), pp. 295-306, 2002. https://doi.org/10.1016/S0168-1656(02)00220-1 in this case study a mutually advantageous full-scale co-treatment solution has been developed and proven, the detailed quality and quantity screening as well as the careful investigation of variability of both domestic and dairy wastewater streams in the particular catchment area are always strictly required for avoiding misdesigned technologies and undesired additional operational costs. The new approach and methodology of this study applied can serve as powerful innovative engineering tool for finding similar cost-effective local solutions.

\section{Acknowledgements}

The project was funded by Budapest Sewage Works Ltd. The valuable contribution and technical assistance of József Simon is highly acknowledged.

[8] Cappai, G., Carucci, A., Onnis, A. "Use of industrial wastewaters for the optimization and control of nitrogen removal processes", Water Science and Technology, 50(6), pp. 17-24, 2004. https://doi.org/10.2166/wst.2004.0354

[9] Quan, Z.-X., Jin, Y.-S., Yin, C.-R., Lee, J. J., Lee, S.-T. "Hydrolyzed molasses as an external carbon source in biological nitrogen removal", Bioresource Technology, 96(15), pp. 1690-1695, 2005. https://doi.org/10.1016/j.biortech.2004.12.033

[10] Sage, M., Daufin, G., Gésan-Guiziou, G. "Denitrification potential and rates of complex carbon source from dairy effluents in activated sludge system", Water Research, 40(14), pp. 2747-2755, 2006. https://doi.org/10.1016/j.watres.2006.04.005

[11] Dragičević, T. L., Hren, M. Z., Grgas, D., Buzdum, I., Čurlin, M. "The potential of dairy wastewater for denitrification", Mljekarstvo, 60(3), pp. 191-197, 2010.

[12] Swinarski, M., Makinia, J., Stensel, H. D., Czerwionka, K., Drewnowski, J. "Modeling External Carbon Addition in Biological Nutrient Removal Processes with an Extension of the International Water Association Activated Sludge Model", Water Environment Research, 84(8), pp. 646-655, 2012. https://doi.org/10.2175/106143012X13373550426670

[13] Jenkins, D., Richard, M. G., Daigger, G. T. "Manual on the Causes and Control of Activated Sludge Bulking, Foaming, and Other Solids Separation Problems", 3rd ed., CRC Press LLC, Boca Raton, Florida, USA, 2004.

[14] Bakos, V., Kiss, B., Jobbágy, A. "Problems and causes of marginal nutrient availability in winery wastewater treatment", Acta Alimentaria, 45(4), pp. 532-541, 2016. https://doi.org/10.1556/066.2016.45.4.10

[15] Jobbágy, A., Kiss, B., Bakos, V. "Conditions Favoring Proliferation of Glycogen Accumulating Organisms for Excess Biological Carbon Removal in Treating Nutrient Deficient Wastewater", Periodica Polytechnica Chemical Engineering, 61(3), pp. 149-155, 2017. https://doi.org/10.3311/PPch.10078 
[16] Sirianuntapiboon, S., Jeeyachok, N., Larplai, R. "Sequencing batch reactor biofilm system for treatment of milk industry wastewater", Journal of Environmental Management, 76(2), pp. 177-183, 2005. https://doi.org/10.1016/j.jenvman.2005.01.018

[17] Scott, J. A., Smith, K. L. "A bioreactor coupled to a membrane to provide aeration and filtration in ice-cream factory wastewater remediation", Water Research, 31(1), pp. 69-74, 1997. https://doi.org/10.1016/S0043-1354(96)00234-5

[18] Fernández-Nava, Y., Marañón, E., Soons, J., Castrillón, L. "Denitrification of high nitrate concentration wastewater using alternative carbon sources", Journal of Hazardous Materials, 173(1-3), pp. 682-688, 2010.

https://doi.org/10.1016/j.jhazmat.2009.08.140

[19) Envirosim 2007 BioWin 3.1 Process Simulator. User Manual for BioWin 3.1. Envirosim Associates Ltd.

[20] Grady, Jr., C. P. L., Daigger, G. T., Lim, H. C. "Biological Wastewater Treatment", 2nd ed., Marcel Decker, Inc., New York, USA, 1999.
[21] Plósz, B. Gy., Jobbágy, A., Grady, Jr., C. P. L. "Factors influencing deterioration of denitrification by oxygen entering an anoxic reactors through the surface", Water Research, 37(4), pp. 853-863, 2003. https://doi.org/10.1016/S0043-1354(02)00445-1

[22] Jobbágy, A., Weinpel, T., Bakos, V., Vánkos, Zs. "Factors potentially converting non-aerated selectors into "low-S - low-DO" basins, effects of seal-covering", In: 12th IWA Specialized Conference on Design, Operation and Economics of Large Wastewater Treatment Plants, Prague, Czech Republic, 2015, pp. $149-155$.

[23] Jobbágy, A., Weinpel, T., Bakos, V. "Excluding Oxygen Penetration from Non-Aerated Selectors: Application of FloatSeal, a New Technology", presented at IWA Conference on Sustainable Wastewater Treatment and Resource Recovery: Research, Planning, Design and Operation, Chongqing, China, Nov. 7-10, 2017. 